\title{
Sicily represents the Italian reservoir of chloroplast DNA diversity of Quercus ilex L. (Fagaceae)
}

\author{
Silvia FineSCHI ${ }^{a *}$, Salvatore COZZOLINO ${ }^{b}$, Marianna MiGLIACCIO $^{b}$, Aldo MUSACCHIO $^{c}$, \\ Michela INNOCENTI ${ }^{\mathrm{d}}$, Giovanni G. VENDRAMIN ${ }^{\mathrm{d}}$ \\ a Consiglio Nazionale delle Ricerche, Istituto per la Protezione delle Piante, Polo Scientifico Sesto Fiorentino, \\ Via Madonna del Piano, Edificio E, 50019 Sesto Fiorentino, Firenze, Italy \\ b Dipartimento Biologia Vegetale, Università di Napoli Federico II, Italy \\ ${ }^{\mathrm{c}}$ Dipartimento di Ecologia, Università della Calabria, Arcavacata di Rende - CS, Italy \\ ${ }^{\mathrm{d}}$ CNR Istituto di Genetica Vegetale, Sezione di Firenze, Italy
}

(Received 14 August 2003; accepted 6 February 2004)

\begin{abstract}
Chloroplast DNA polymorphism was analysed in forty-four Italian holm oak populations. Results obtained with different markers (PCR-RFLP and SSR) were congruent, showing a clear geographic structure of genetic diversity and high value of genetic differentiation $\left(G_{\mathrm{ST}}=\right.$ $0.80)$. By combining PCR-RFLP and SSR, eight haplotypes were identified in Italy, six of them in Sicily. Most populations were fixed for one haplotype. Some populations from the extreme West Mediterranean (Morocco) and the extreme East Mediterranean areas (Crete) were interpreted as reproductively isolated populations because they had completely different haplotypes. These results strongly support the hypothesis of glacial refugia existing in southern Italy, and underline the high conservation value of natural tree populations in Sicily, in which most diversity was detected.
\end{abstract}

\section{Quercus ilex / PCR-RFLP / SSR / genetic differentiation}

Résumé - La Sicile, réservoir italien de la diversité de l'ADN chloroplastique de Quercus ilex L. Le polymorphisme de l'ADN chloroplastique a été analysé chez 44 populations italiennes de chêne vert. Les résultats obtenus avec différents marqueurs (PCR-RFLP et SSR) ont été cohérents, montrant clairement une structure géographique de la diversité génétique et une valeur élevée de la différentiation génétique $\left(\mathrm{G}_{\mathrm{ST}}=\right.$ 0,80). En combinant PCR-RFLP et SSR, huit haplotypes ont été identifiés en Italie dont six en Sicile. La plupart des populations ont été fixées par un haplotype. Des populations de l'extrême ouest méditerranéen (Maroc) et de l'extrême est (Crète) ont été interprétées comme des reproductions de populations isolées parce qu'elles ont des haplotypes différents. Ces résultats supportent fortement l'hypothèse d'un refuge glaciaire existant dans le Sud de l'Italie et soulignent la grande importance de la conservation des populations d'arbres en Sicile dans lesquelles une grande diversité a été détectée.

Quercus ilex / PCR-RFLP/SSR / différentiation génétique

\section{INTRODUCTION}

Lumaret et al. [18] recently analysed the variation of chloroplast DNA in Quercus ilex over its whole distribution range. Their results indicated that post-glacial recolonisation probably started from the three Mediterranean peninsulas, as already suggested and demonstrated for several animal and plant species $[2,15,16,30]$ including deciduous oaks $[3,10,13,21,24]$.

In the study by Lumaret et al. [18], which is based on RFLP of the whole chloroplast genome, Italy and south-eastern France appeared to have been colonised by one major haplotype. Additional haplotypes were rarely detected in continental
Italy and in the islands of Corsica and Sicily, and no Balkan haplotype was detected along the Italian Adriatic coast. Opposite to that, deciduous oaks phylogeography has shown that the Italian and the Balkan peninsulas share two major haplotypes, whose occurrence in the different areas may be ascribed either to the presence of the same haplotype in the two different refugia, or to the migration that took place through the Adriatic bridge during glacial period [13, 24].

On the basis of the results by Lumaret et al. [18] we analysed in more detail the chloroplast DNA diversity in Italy and particularly in Sicily. As compared to that study we wanted to investigate more deeply the haplotype distribution within the

\footnotetext{
* Corresponding author: s.fineschi@ipp.cnr.it
} 
Italian peninsula in order to identify the potential refugial areas of holm oak. Our sampling was particular intense in Sicily because this island is characterised by elevated biodiversity and a high number of endemic species [8].

Among the European evergreen oaks, holm oak is the most widely distributed species; in the Italian peninsula it is widespread from north to south along both the Tyrrhenian and the Adriatic coasts, and in the main islands Sicily and Sardinia.

According to Huntley and Birks [17], the history of European evergreen oaks during the last interglacial is not well known; however, fossil pollen records suggest that this group of oaks was present around the Mediterranean during the last interglacial, where it survived throughout the last glacial period. In the late glacial and early Holocene (10 000 years BP) colonisation probably started from the Eastern Mediterranean refugia, and increased rapidly as climate improved. In the last 2000 years a decline of pollen records was registered, which might result from anthropogenic clearance of the Mediterranean regions [17].

In this work we analysed Italian holm oak populations with chloroplast (PCR-RFLP and SSR) markers. Additional populations sampled in other countries (Crete, Croatia, Slovenia, and Morocco) were also included in this study. The main objectives were: (i) to quantify the chloroplast genetic diversity of this species and its geographic distribution in Italy; (ii) to verify if Sicily represents a hotspot of diversity for holm oak, and to test its possible role in the migration history along the Italian peninsula.

\section{MATERIALS AND METHODS}

Forty four holm oak populations were collected in Italy, eighteen of them in Sicily. Each population was represented by 3 to 11 individuals (the island of Vulcano was represented by only one individual). Name of locations, geographic co-ordinates, and number of individuals per population are indicated in Table I. In addition, one $Q$. ilex population from the island of Crete, two from Morocco, one from Slovenia, and two from Croatia were also analysed.

Total DNA was extracted from frozen leaves using QIAGEN Dnaeasy Plant kit. All populations were analysed by chloroplast (PCRRFLP and SSR) markers.

Chloroplast DNA was amplified using universal primers (fragment TF: [29]; fragments CD, DT, AS, HK, K1K2, CS: [6]; fragment FV: [11]). Amplification, digestion, and electrophoretic procedures are described in Demesure et al. [7] and Fineschi et al. [12].

Six chloroplastic microsatellite regions were amplified using specific primer pairs (ccmp2, ccmp3, ccmp4, ccmp5, ccmp7, ccmp10) [32]. PCR amplifications and sizing of the fragments were performed as described by Vendramin and Ziegenhagen [31]. Amplified fragments of the two polymorphic chloroplast microsatellites were cloned into plasmid vectors using the Invitrogen TOPO cloning kit and then sequenced from both ends using an automatic sequencer Alf Express (Pharmacia). Each fragment was sequenced twice.

Diversity and differentiation parameters were calculated according to Pons and Petit [26, 27] using the software PERMUT (http:// www.pierroton.inra.fr/genetics/labo/Software): the average within population gene diversity $\left(h_{S}\right)$, the total gene diversity $\left(h_{T}\right)$, and the differentiation for unordered alleles $\left(G_{\mathrm{ST}}\right)$ and for ordered alleles $\left(N_{\mathrm{ST}}\right)$. Thousand random permutations of haplotypes identities were made, keeping the haplotype frequencies and the matrix of pairwise haplotype differences as in the original study [4]. For this analysis only populations represented by more than two individuals were considered (the population from Vulcano was excluded). The distribution of values obtained by permutation was compared with the observed values. For the $N_{\mathrm{ST}}$ analysis, a distance matrix derived from the pairwise number of mutational differences between haplotypes was used. According to Pons and Petit [27] significantly higher values for $N_{\mathrm{ST}}$ than for $G_{\mathrm{ST}}$ indicate the existence of a phylogeographic structure.

Statistical parsimony was used to reconstruct phylogenetic relationships between haplotypes (TCS, version 1.06, [5]) by combining PCR-RFLP and microsatellite data.

\section{RESULTS}

Six out of sixteen primer-enzyme combinations were polymorphic and led to the identification of eleven different PCRRFLP haplotypes (Tabs. I and II). All mutations were caused by insertion/deletion, no point mutation was detected. Two microsatellite regions out of six showed polymorphysm in $Q$. ilex: ccmp4 and ccmp10, which displayed three variant each. Sequencing revealed that the three SSR haplotypes differed in the number of repeats within the microsatellite regions (accession numbers: AY465917, AY465918, AY465919, AY465920, AY465921, AY465922).

By combining PCR-RFLP and SSR, eight haplotypes were identified in Italy (Fig. 1), six of them in Sicily (haplotypes number 1,2,3,6,7, and 8). Additional haplotypes were detected in the island of Crete (9 and 10), and in Morocco (haplotype 11).

Some Italian haplotypes were very rare and restricted to Sicily (number 1, 7, and 8). Haplotype 5, the most frequent one (0.36), was widely distributed over the whole Italian peninsula and in Sardinia, but it was absent in Sicily. Among the most frequent haplotypes (number 3: 0.25 , number 2: 0.15 , and number 6: 0.14 ) only haplotype 3 was distributed outside of Sicily. Haplotype 4 was detected only in Calabria.

Most populations (12 out of 18 in Sicily and 23 Italian, Slovenian, Croatian, and Moroccan populations out of 31) were monomorphic. In the most polymorphic sites (populations 16: Monte Pellegrino, 17: San Rizzo, 19: Reggio Calabria, and 28: Avellino) three haplotypes were identified.

The presence of haplotype 2 in one Apennine population (32: Larino) has to be interpreted as an artificial introduction: indeed such haplotype occurs only in Sicily and particularly in the south-eastern part of the island, close to the Etna region.

Haplotype 6 characterises the south-western part of Sicily, including the island of Pantelleria. One individual having this haplotype was identified in population 28 (Avellino): this result is not surprising because historical records report evidences of some artificial seed transfer in this area from Sicily [22].

The analysis of genetic diversity revealed high value of genetic differentiation: $G_{\mathrm{ST}}=0.802$ (se $=0.047$ ). The coefficient of genetic differentiation for ordered alleles $N_{\mathrm{ST}}=0.811$ (se $=0.056$ ) was not significantly different from $G_{\mathrm{ST}}$. Average genetic diversity within populations $\left(h_{S}\right)$ and total genetic diversity $\left(h_{T}\right)$ were equal to $0.153(\mathrm{se}=0.038)$ and $0.774(\mathrm{se}=$ 0.033 ) respectively.

The cladogram of cpDNA haplotypes, as inferred using statistical parsimony, indicated that haplotypes 1 and 2 were the most divergent among the Italian ones. The haplotypes detected 
Table I. Distribution of PCR-RFLP haplotypes within populations of $Q$. ilex.

\begin{tabular}{|c|c|c|c|c|c|c|c|c|c|c|c|c|c|c|}
\hline \multirow[t]{2}{*}{ Population } & \multirow[t]{2}{*}{ Long. } & \multirow[t]{2}{*}{ Latit. } & \multicolumn{11}{|c|}{ Haplotype } & \multirow[t]{2}{*}{ Sample size } \\
\hline & & & 1 & 2 & 3 & 4 & 5 & 6 & 7 & 8 & 9 & 10 & 11 & \\
\hline 1 Gelfiser - Kaggiar & 12.20 & 36.83 & - & - & - & - & - & 11 & - & - & - & - & - & 11 \\
\hline 2 Montagna Grande & 11.93 & 36.83 & - & - & - & - & - & 10 & - & - & - & - & - & 10 \\
\hline 3 Cava Randello & 14.57 & 36.88 & - & 5 & - & - & - & - & - & - & - & - & - & 5 \\
\hline 4 Cava Grande & 15.03 & 37.15 & - & 6 & - & - & - & - & - & - & - & - & - & 6 \\
\hline 5 Menfi & 12.97 & 37.60 & - & - & - & - & - & 6 & - & - & - & - & - & 6 \\
\hline 6 Portella Daini & 13.75 & 37.63 & - & 1 & - & - & - & 4 & - & - & - & - & - & 5 \\
\hline 7 Monte Altesina & 14.38 & 37.63 & - & 6 & - & - & - & - & - & - & - & - & - & 6 \\
\hline 8 Bosco Adriano & 13.37 & 37.68 & - & - & - & - & - & 3 & - & - & - & - & - & 3 \\
\hline 9 Monte Carcaci & 13.45 & 37.80 & - & - & - & - & - & 6 & - & - & - & - & - & 6 \\
\hline 10 Ficuzza & 13.30 & 37.82 & - & 3 & - & - & - & - & - & 2 & - & - & - & 5 \\
\hline 11 Etna & 15.13 & 37.83 & - & 5 & - & - & - & - & 1 & - & - & - & - & 6 \\
\hline 12 San Guglielmo & 14.08 & 37.93 & - & - & 5 & - & - & - & - & - & - & - & - & 5 \\
\hline 13 Piano Zucchi & 14.00 & 37.95 & - & - & 6 & - & - & - & - & - & - & - & - & 6 \\
\hline 14 Mongerbino & 13.65 & 37.98 & - & 9 & - & - & - & - & - & - & - & - & - & 9 \\
\hline 15 Monte Sparagio & 12.78 & 38.02 & - & - & 6 & - & - & - & - & - & - & - & - & 6 \\
\hline 16 Monte Pellegrino & 13.37 & 38.12 & 3 & - & 2 & - & - & - & 1 & - & - & - & - & 6 \\
\hline 17 S. Rizzo & 15.47 & 38.40 & 2 & - & 3 & - & - & - & 1 & - & - & - & - & 6 \\
\hline 18 Vulcano & 14.95 & 38.41 & - & - & - & - & - & - & 1 & - & - & - & - & 1 \\
\hline 19 Reggio Calabria & 15.65 & 38.10 & - & - & 1 & 4 & 1 & - & - & - & - & - & - & 6 \\
\hline 20 Cosenza & 16.25 & 39.30 & - & - & 1 & 5 & - & - & - & - & - & - & - & 6 \\
\hline 21 Talana & 9.50 & 40.03 & - & - & - & - & 6 & - & - & - & - & - & - & 6 \\
\hline 22 Rauccio & 18.18 & 40.38 & - & - & 5 & - & - & - & - & - & - & - & - & 5 \\
\hline 23 Calciano & 16.18 & 40.58 & - & - & - & - & 5 & - & - & - & - & - & - & 5 \\
\hline 24 Sos Rios & 9.36 & 40.68 & - & - & 5 & - & - & - & - & - & - & - & - & 5 \\
\hline 25 Montes & 8.68 & 40.68 & - & - & 2 & - & 3 & - & - & - & - & - & - & 5 \\
\hline 26 Putignano & 17.12 & 40.85 & - & - & - & - & 6 & - & - & - & - & - & - & 6 \\
\hline 27 Capodimonte & 14.23 & 40.88 & - & - & - & - & 4 & - & - & - & - & - & - & 4 \\
\hline 28 Avellino & 14.78 & 40.90 & - & - & 1 & - & 1 & 1 & - & - & - & - & - & 3 \\
\hline 29 Sant'Agapito & 14.22 & 41.55 & - & - & 6 & - & - & - & - & - & - & - & - & 6 \\
\hline 30 San Marco in Lamis & 15.63 & 41.72 & - & - & - & - & 5 & - & - & - & - & - & - & 5 \\
\hline 31 Castelporziano & 12.42 & 41.75 & - & - & - & - & 8 & - & - & - & - & - & - & 8 \\
\hline 32 Larino & 14.88 & 41.80 & - & 7 & - & - & 2 & - & - & - & - & - & - & 9 \\
\hline 33 Càsoli & 14.30 & 42.12 & - & - & - & - & 5 & - & - & - & - & - & - & 5 \\
\hline 34 Fara Sabina & 12.72 & 42.20 & - & - & 9 & - & 1 & - & - & - & - & - & - & 10 \\
\hline 35 Civitella del Lago & 12.28 & 42.67 & - & - & - & - & 10 & - & - & - & - & - & - & 10 \\
\hline 36 Rapolano Terme & 11.60 & 43.28 & - & - & - & - & 6 & - & - & - & - & - & - & 6 \\
\hline 37 Castiglioncello & 10.40 & 43.40 & - & - & 6 & - & - & - & - & - & - & - & - & 6 \\
\hline 38 Cavriglia & 11.48 & 43.52 & - & - & - & - & 5 & - & - & - & - & - & - & 5 \\
\hline 39 Tirrenia & 10.30 & 43.62 & - & - & 1 & - & 5 & - & - & - & - & - & - & 6 \\
\hline 40 Ancona & 13.50 & 43.63 & - & - & - & - & 5 & - & - & - & - & - & - & 5 \\
\hline 41 Riomaggiore & 9.73 & 44.10 & - & - & - & - & 6 & - & - & - & - & - & - & 6 \\
\hline 42 Bosco Mesola & 12.40 & 44.88 & - & - & - & - & 6 & - & - & - & - & - & - & 6 \\
\hline 43 Garda & 10.70 & 45.57 & - & - & - & - & 6 & - & - & - & - & - & - & 6 \\
\hline 44 Duino & 13.36 & 45.77 & - & - & - & - & 6 & - & - & - & - & - & - & 6 \\
\hline $45 \mathrm{Krk}$ & 14.30 & 45.00 & - & - & 3 & - & - & - & - & - & - & - & - & 3 \\
\hline 46 Zadar & 15.50 & 44.00 & - & - & 3 & - & 1 & - & - & - & - & - & - & 4 \\
\hline 47 Solkan & 13.67 & 45.97 & - & - & 5 & - & - & - & - & - & - & - & - & 5 \\
\hline 48 Imbròs Gorge & 24.50 & 35.50 & - & - & - & - & - & - & - & - & 2 & 3 & - & 5 \\
\hline 49 El Anasser & -5.00 & 35.02 & - & - & - & - & - & - & - & - & - & - & 3 & 3 \\
\hline \multirow[t]{3}{*}{50 Beni Salleh } & -5.02 & 35.03 & - & - & - & - & - & - & - & - & - & - & 3 & 3 \\
\hline & & Total & 5 & 42 & 70 & 9 & 103 & 41 & 4 & 2 & 2 & 3 & 5 & 286 \\
\hline & & Frequency & 0.017 & 0.147 & 0.245 & 0.031 & 0.360 & 0.143 & 0.014 & 0.007 & 0.007 & 0.010 & 0.017 & 1 \\
\hline
\end{tabular}




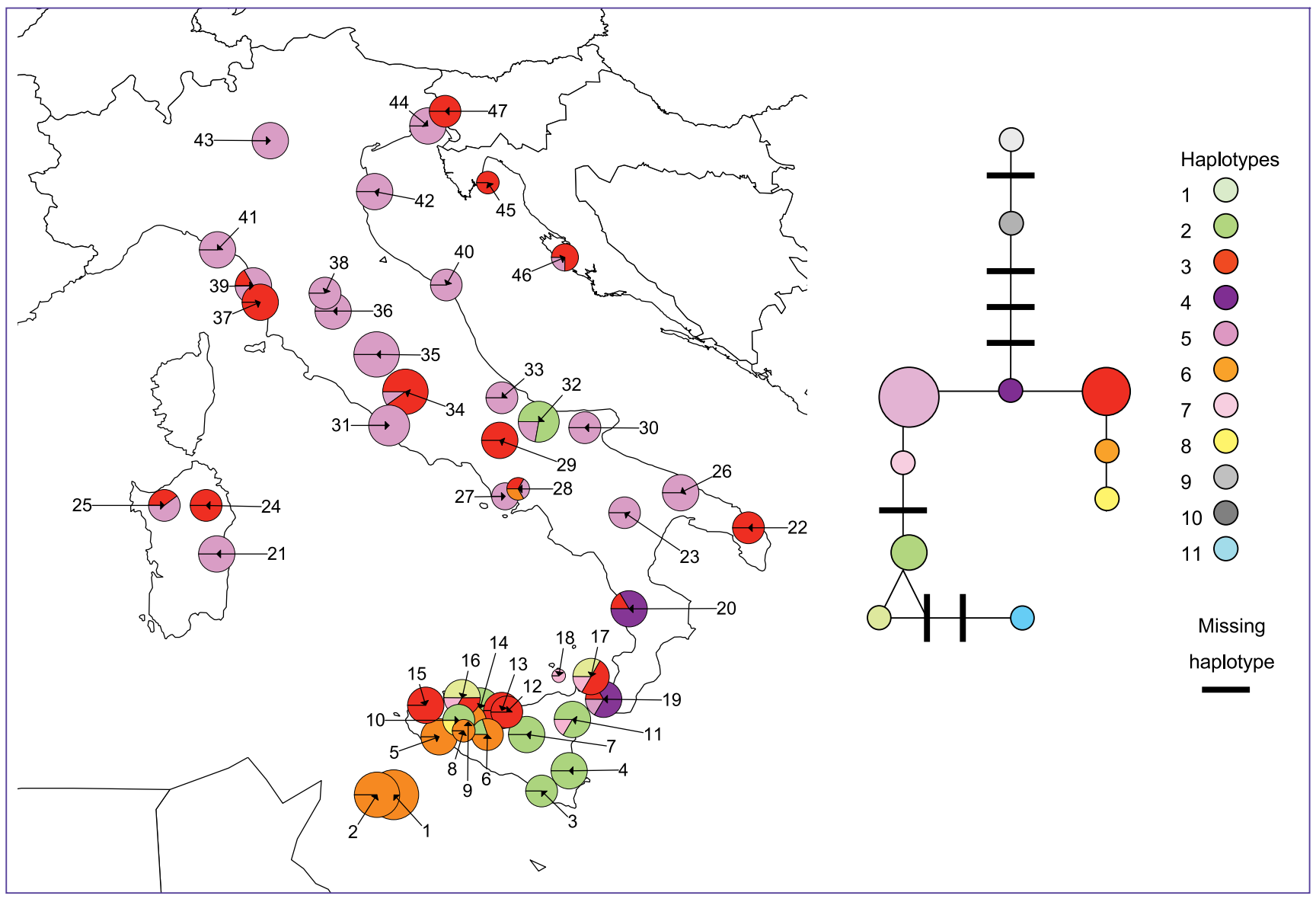

Figure 1. Distribution and frequency of cpDNA haplotypes within $Q$. ilex populations and phylogenetic reconstruction of the relationships among haplotypes using statistical parsimony. Size of the pies indicates the number of individuals for each population (from 1 to 10). Haplotypes 9 to 11, referring to populations from Crete and Morocco, are not shown in the map.

Table II. Description of PCR-RFLP and SSR haplotypes identified in Q. ilex.

\begin{tabular}{|c|c|c|c|c|c|c|c|c|c|c|}
\hline \multirow[b]{2}{*}{ Haplotype } & \multicolumn{8}{|c|}{ PCR-RFLP fragments (approximate size in bp) } & \multicolumn{2}{|c|}{ Microsatellite (size in bp) } \\
\hline & $\begin{array}{l}\text { DT Taq } \\
\text { Band I }\end{array}$ & $\begin{array}{l}\text { HK Taq } \\
\text { Band II }\end{array}$ & $\begin{array}{l}\text { AS Hinf } \\
\text { Band III }\end{array}$ & $\begin{array}{l}\text { CD Hinf } \\
\text { Band III }\end{array}$ & $\begin{array}{l}\text { FV Taq } \\
\text { Band I }\end{array}$ & $\begin{array}{l}\text { FV Taq } \\
\text { Band III }\end{array}$ & $\begin{array}{l}\text { TF Hinf } \\
\text { Band I }\end{array}$ & $\begin{array}{l}\text { TF Hinf } \\
\text { Band III }\end{array}$ & ccmp4 & ccmp10 \\
\hline 1 & 680 & 600 & 450 & 280 & 820 & 270 & 400 & 150 & 117 & 118 \\
\hline 2 & 680 & 520 & 450 & 280 & 820 & 270 & 400 & 150 & 117 & 118 \\
\hline 3 & 600 & 520 & 450 & 400 & 800 & 300 & 400 & 130 & 116 & 119 \\
\hline 4 & 600 & 520 & 450 & 400 & 800 & 300 & 400 & 150 & 116 & 119 \\
\hline 5 & 600 & 520 & 450 & 400 & 800 & 270 & 400 & 150 & 116 & 119 \\
\hline 6 & 600 & 520 & 400 & 400 & 800 & 300 & 400 & 130 & 116 & 119 \\
\hline 7 & 600 & 520 & 450 & 280 & 800 & 270 & 400 & 150 & 116 & 119 \\
\hline 8 & 600 & 520 & 400 & 280 & 800 & 300 & 400 & 130 & 116 & 119 \\
\hline 9 & 680 & 400 & - & 370 & 780 & 200 & 400 & 130 & 116 & 119 \\
\hline 10 & 680 & 400 & - & 320 & 780 & 200 & 400 & 150 & 116 & 119 \\
\hline 11 & 680 & 400 & 450 & 180 & 820 & 270 & 350 & 150 & 115 & 117 \\
\hline
\end{tabular}


in Crete (9 and 10) and in Morocco (11) clearly belonged to different lineages (Fig. 1).

\section{DISCUSSION}

The coefficient of population subdivision calculated in this study for $Q$. ilex $\left(G_{\mathrm{ST}}=0.80\right)$ is of the same order of magnitude than the mean value reported for maternal inherited genomes in angiosperm tree species: $G_{\mathrm{ST}}=0.73$ [23], and very close to that calculated for sessile oak, $G_{\mathrm{ST}}=0.83$ [10].

In oaks, organelle genomes are maternally inherited [9]; seeds are dispersed mostly by gravity around the mother tree, and by animals (acorns are cached by birds and small mammals). Consequently, high levels of differentiation among populations are expected. Indeed, the $G_{\mathrm{ST}}$ value measured in the present study for holm oak populations is consistent with estimates reported for other oak species [24], although Lumaret et al. [18] obtained higher value of population subdivision $\left(G_{\mathrm{ST}}=\right.$ 0.92 ) over the whole distribution of $Q$. ilex.

On the other hand, $G_{\mathrm{ST}}$ value calculated for Moroccan holm oak was lower: $G_{\mathrm{ST}}=0.33$ [1]. According to the authors, such low value might be caused by the limited sample size (165 individuals), the low levels of cpDNA diversity of this species in Morocco, and the occasional but incomplete introgression with Q. suber detected in sympatric populations [1].

Six out of eight Italian haplotypes were detected in Sicily, and one of them (haplotype 3) was also found in peninsular Italy. Results by Lumaret et al. [18] demonstrated that a single haplotype, out of three detected in Sicily, was also present in the whole Italian peninsula, in the islands of Sardinia and Corsica, and in south-eastern France. It should be taken into account that different methods for hapotype identification were applied in the survey by Lumaret et al. [18] (RFLP after digestion with 6- and 4-cutter endonucleases) and in the present study (PCR-RFLP). Therefore, our haplotypes number 3, 4, and 5 likely represent haplotype 4 described by Lumaret et al. [18].

On the base of molecular data and in the absence of macrofossil evidences, the direction of the migration followed by holm oak after the last glacial period can only be based on assumptions. In fact, a migration from potential central Italian refugia towards north but also towards south is not unlikely, because the presence of holm oak in this part of the peninsula during previous interglacial (250 000 years $\mathrm{BP}$ ) is recorded [14].

Our haplotype number 3 might have migrated from the southern Italian refugium at the end of last glacial period colonising new areas. Alternatively, and most likely, penisular Italy could have been colonized from local refugia, well documented in southern and central Italy, as remnants of a widespread diffusion of $Q$. ilex during the last interglacial [14]. The age of the postglacial spread of holm oak in southern France [25], clearly younger than in central Italy, where it started already in the late glacial $[14,19]$, rules out that haplotypes 3 and 5 migrated from France southward into central Italy.

In contrast to the significant expansions of $Q$. ilex that took place in Italy, the Sicilian private haplotypes $(1,2,6,7$, and 8$)$ might be the remnant of a more ancient $Q$. ilex distribution that did not appreciably expand during the postglacial and so did not contribute to the colonisation of the peninsula. In fact, according to Sadori and Narcisi [28] the presence of holm oak in Sicily was conspicuous already at the beginning of Holocene.

The general picture obtained by our study seems to support the hypothesis formulated by Lumaret et al. [18] about the colonisation processes of the Italian peninsula; moreover, it gives evidence about the importance of Sicily for the conservation of haplotype diversity. In this sense, it is worth to underline the haplotype richness detected in Sicily. Three haplotypes (1, 7, and 8 ) are very rare and appear only in few populations. However, the artificial introduction of these haplotypes from other Italian regions can be excluded because of their absence elsewhere. On the other hand, haplotypes 2 and 6 are more frequent ( 0.15 and 0.14$)$ despite the fact that their occurrence is limited to Sicily.

It is further worth stressing that the geographic structure of haplotype distribution in Sicily was maintained in spite of the range fragmentation and the intense human impact on the forest and agricultural landscape experienced by the island during the last centuries.

On the basis of our results we can conclude that Sicily represents the Italian reservoir for holm oak haplotypic diversity, thus increasing the conservation value of this area. The analysis of nuclear markers (isozymes) over the whole species distribution revealed that some Sicilian populations were characterised by the occurrence of private alleles [20]. Such evidences underline the need to increase conservation efforts for the preservation of biodiversity in this area, also considering that in Sicily unique tree species like Abies nebrodensis and Zelkova sicula survived as relict. It should be stressed that chloroplast diversity is not necessarily related to adaptive variation, i.e. the component of genetic diversity that should be conserved to maintain high adaptive potential. In this contest, the conservation value of Sicilian holm oak populations should be confirmed by studies on adaptive diversity.

Acknowledgements: We are grateful to A. Bevacqua. D. Salvini, and D. Taurchini for their help. We acknowledge: A. Cabiddu, S. Delfine, A. de Leonardis, T. La Mantia, D.S. La Mela Veca, M. Michelozzi, P. Nascetti, R. Papa, M.H. Pemonge, D. Slade, L. Todaro, F. Talone, V. Vremech, and the Italian Forest Service (CFS) from Bosco Mesola and Peri for collecting and sending Quercus ilex material. We warmly thank Roselyne Lumaret (Montpellier), M. Lascoux (Uppsala), and Donatella Magri (Rome), for critical reading of the manuscript. This research was partly supported by the European Union (FESR Fondo Europeo Sviluppo Regionale).

\section{REFERENCES}

[1] Belahbib N., Pemonge M.H., Ouassou A., Sbay H., Kremer A., Petit R.J., Frequent cytoplasmic exchanges between oak species that are not closely related: Quercus suber and Q. ilex in Morocco, Mol. Ecol. 10 (2001) 2003-2012.

[2] Bennett K.D., Tzedakis P.C., Willis K.J., Quaternary refugia of the North Europeans trees, J. Biogeogr. 18 (1991) 103-115.

[3] Brewer S., Cheddadi R., de Beaulieu J.-L., Reille M., The spread of deciduous Quercus throughout Europe since the last glacial period, For. Ecol. Manage. 156 (2002) 27-48.

[4] Burban C., Petit R.J., Carcreff E., Jactel H., Rangewide variation of the maritime pine bast scale Matsucoccus feytaudi Duc. (Homoptera: 
Matsucoccidea) in relation to the genetic structure of its host, Mol. Ecol. 8 (1999) 1593-1602.

[5] Clement M.D., Posada M.D., Crandall K.A., TCS: a computer program to estimate gene genealogies, Mol. Ecol. 9 (2000) 1657-1660

[6] Demesure B., Sodzi N., Petit R.J., A set of universal primers for amplification of polymorphic non-coding regions of mitochondrial and chloroplast DNA in plants, Mol. Ecol. 4 (1995) 129-131.

[7] Demesure B., Comps B., Petit R.J., Chloroplast DNA phylogeography of the common beech (Fagus sylvatica L.) in Europe, Evolution 50 (1996) 2510-2515.

[8] Di Martino F., Raimondo F.M., Biological and chorological survey of the Sicilian flora, Webbia 34 (1980) 309-335.

[9] Dumolin S., Demesure B., Petit R.J., Inheritance of chloroplast and mitochondrial genomes in pedunculate oak investigated with an efficient PCR-based method, Theor. Appl. Genet. 91 (1995) 1253 1256.

[10] Dumolin-Lapègue S., Demesure B., Le Corre V., Fineschi S., Petit R.J., Phylogeographic structure of white oaks throughout the European continent, Genetics 146 (1997) 1475-1487.

[11] Dumolin-Lapègue S., Pemonge M.H., Petit R.J., An enlarged set of consensus primers for the study of organelle DNA in plants, Mol. Ecol. 6 (1997) 393-397.

[12] Fineschi S., Taurchni D., Villani F., Vendramin G.G., Chloroplast DNA polymorphism reveals little geographical structure in Castanea sativa Mill. (Fagaceae) throughout southern European countries, Mol. Ecol. 9 (2000) 1495-1503.

[13] Fineschi S., Taurchini D., Grossoni P., Vendramin G.G., Chloroplast DNA variation of white oaks in Italy, For. Ecol. Manage. 156 (2002) 103-114.

[14] Follieri M., Magri D., Sadori L., 250 000-year pollen record from Valle di Castiglione (Roma), Pollen Spores 30 (1988) 329-256.

[15] Hewitt G.M., Some genetic consequences of ice ages and their role in divergence and speciation, Biol. J. Linn. Soc. 58 (1996) 247276.

[16] Hewitt G.M., Post-glacial re-colonisation of European biota, Biol. J. Linn. Soc. 68 (1999) 87-112.

[17] Huntley B., Birks H.J.B., An atlas of past and present pollen maps for Europe: 0-13 000 years ago, Cambridge University Press, Cambridge, 1983 .

[18] Lumaret R., Mir C., Michaud H., Raynal V., Phylogeographical variation of chloroplast DNA in holm oak (Quercus ilex L.), Mol. Ecol. 11 (2002) 2327-2336.
[19] Magri D., Late Quaternary vegetation history at Legaccione near Lago di Bolsena (central Italy), Rev. Paleobot. Palynol. 106 (1999) 171-208.

[20] Michaud H., Toumi L., Lumaret R., Li T.X., Romane F., Di Giusto F., Effect of geographical discontinuity on genetic variation in Quercus ilex L. (holm oak). Evidence from enzyme polymorphism, Heredity 74 (1995) 590-606.

[21] Olalde M., Herran A., Espinel S., Goicoechea P.G., White oaks phylogeography in the Iberian peninsula, For. Ecol. Manage. 156 (2002) 89-102.

[22] Pasquale G.A., Documenti biografici di Giovanni Gussone Botanico Napoletano tratti dalle sue opere e specialmente dal suo erbario, Atti Accademia Pontaniana 10 (1871) 1-56.

[23] Petit R.J., Diversité génétique et histoire des populations d'arbres forestiers, Dossier d'habilitation à diriger des recherches, Université de Paris-Sud, UFR Scientifique d'Orsay, 1999.

[24] Petit R.J., Csaikl U.M., Bordacs S., et al., Chloroplast DNA variation in European white oaks. Phylogeography and patterns of diversity based on data from over 2600 populations, For. Ecol. Manage. 156 (2002) 5-26.

[25] Planchais N., Impact de l'homme lors du remplissage de l'estuaire de Lez (Palavas, Hérault) mis en évidence par l'analyse pollinique, Pollen Spores 29 (1987) 73-88.

[26] Pons O., Petit R.J., Estimation, variance and optimal sampling of gene diversity. 1. Haploid locus, Theor. Appl. Genet. 90 (1995) 462-470.

[27] Pons O., Petit R.J., Measuring and testing genetic differentiation with ordered versus unordered alleles, Genetics 144 (1996) 1237 1245 .

[28] Sadori L., Narcisi B., The post-glacial record of environmental history from Lago di Pergusa, Sicily, Holocene 11 (2001) 655-671.

[29] Taberlet P., Gielly L., Patou G., Bouvet J., Universal primers for amplification of three non-coding regions of chloroplast DNA, Plant Mol. Biol. 17 (1991) 1105-1109.

[30] Taberlet P., Fumagalli L., Wust-Saucy A.G., Cosson J.F., Comparative phylogeography and postglacial colonization routes in Europe, Mol. Ecol. 7 (1998) 453-464.

[31] Vendramin G.G., Ziegenhagen B., Characterization and inheritance of polymorphic plastid microsatellites in Abies, Genome 40 (1997) 857-864.

[32] Weising K., Gardner R.C., A set of conserved PCR primers for the analysis of simple sequence repeat polymorphisms in chloroplast genomes of dicotyledonous angiosperms, Genome 42 (1999) 9-19. 